\title{
The problem of "culture" in the process of intercultural understanding
}

\author{
Andreana Marchi \\ Middlebury College \\ Middlebury, VT, USA \\ E. Doyle McCarthy ${ }^{* *}$ \\ Fordham University \\ New York, NY, USA
}

\begin{abstract}
The problem of "culture" in the process of intercultural understanding is one of the most discussed issues among scholars today. Anthropologists, linguists, literary critics, and philosophers, just to name a few, study this issue using a problem-based and research format. Culture and cultural understanding are hereby presented by demonstrating studies and observations of two cultural anthropologists, R. H. Robbins and Clifford Geertz, a literary critic, Lionel Trilling, and C. S. Lewis, a famous writer of both fiction and non-fiction. Our intention here is to answer the question: how to describe and analyze a culture that is so different from the perspective of our own? In this sense, language and discourse are also analyzed in this paper as part of culture and can indicate some of our own moral perspectives and judgments on others' cultures.
\end{abstract}

Keywords: Culture; Intercultural Understanding; Ethics

\section{Introduction}

As the problem of "culture" in the process of intercultural understanding is one of the most discussed issues among scholars today, we argue that it is possible to bridge some of Mark Twain's observations presented by Robbins (1993) along with an anthropological analysis carried out by Clifford Geertz (1983) in Java in which both try to understand a foreign culture through different lenses. In addition to that, the literary critic Lionel Trilling contributes in this paper to the moral debate with his observations in a lecture entitled, "Why We Read Jane Austen” (1974). Trilling analyzes his students' reactions and confrontations when dealing with Austen's moral and ethical meanings not only in her time but also in the time the lecture was given. In the same way, we will draw from the examples presented by C. S. Lewis (2009), in his essay "A Note on Jane Austen", namely, how Austen construes the moral behavior of her characters as well as how she describes the ethical backgrounds in her novels.

The relations among these observations might suggest how we ethically/morally act and behave towards others and ourselves. In addition, one might see how an anthropological investigation can lead us to a better understanding of a culture "so different,"

\footnotetext{
Andreana Marchi is Assistant of Portuguese at Middlebury College in Middlebury, VT, USA. Her research and teaching interests are in the fields of mother tongue and foreign language. She is also interested in the relationship between language, culture, and society. Andreana Marchi holds a M.A. in English Language and Literature from the Federal University of Santa Catarina (UFSC), Florianopolis, SC, Brazil. She is a member of the American Organization of Teachers of Portuguese. Email: amarchi@middlebury.edu

${ }^{*}$ E. Doyle McCarthy is Professor of Sociology at Fordham University in New York. Her research and writing are in the fields of the sociology of knowledge and culture and in the interdisciplinary field of emotion studies. McCarthy's current research is on the culture of emotions in contemporary life in the U.S. She is a member of the International Society for Research on Emotion (ISRE). Since 2007, she has served on the advisory board of the international journal, La Critica Sociologica (Comitato scientifio). She is a member of Fordham University's Center for Ethics Education. Email: mccarthy@fordham.edu
} 
if compared to our own as well as how Jane Austen's world can be perceived through the moral realms of her time and our own. The problems are similar - as Geertz has argued. For the reading and the appeal of nineteenth century novels by late twentieth century students is comparable in many ways to the problem of anthropology and ethnography: namely, how can we understand and describe in writing a culture foreign to our own.

\section{The Problem of Us and Them through the Eyes of Twain and Malinowski}

In order to have an anthropological understanding of intercultural meanings that pervade our cultural context and the meanings of others, some considerations deserve attention. In this sense, the observations of Robbins and Geertz in the area of anthropology are analyzed and discussed in the beginning of this paper. Robbins (1993) and Geertz (1983) demonstrate certain similarities in ideas about the comparison between the problem of "us and them," ourselves and the Other. Robbins (1993, p. 2) introduces the topic by presenting Mark Twain's impressions through his travels in Europe in 1867, pointing out some striking descriptions by Twain on the people of the Azores, Greece, and Italy by his confrontations with different cultures. In one of the descriptions mentioned by Robbins (1993), Twain did not spare any effort to describe the Greek way of living and being as "everybody lies and cheats - everybody who is in business, at any rate. Even foreigners soon have to come down to the custom of the country, and they do not buy and sell long in Constantinople till they lie and cheat like a Greek" (p. 2). Twain's descriptions of the others could be considered harsh and ethnocentric, but as Robbins notes he was also known as a "gentle" observer and interpreter of his fellow Americans.

The contemporary philosopher Charles Taylor (1992) suggests that there are benefits to embracing multiculturalism and the tendency that we need to recognize, "the other" as ourselves. However, if we take into account Twain's descriptions on the others, it seems that Twain is not recognizing "the other" from a positive or even a neutral perspective, since he imagines Greeks, Italians, and the people of the Azores, i.e., he is observing and judging them as he would any American. Taylor (1992) argues that "nonrecognition or misrecognition can inflict harm, can be a form of oppression, imprisoning someone in a false, distorted, and reduced mode of being" (p. 25). As Twain describes "the others", he is using language to construe meaning (clearly not a positive one), but taking as a starting point what he knows of his own culture, what he "judges" to be right or ethical. In a sense, he is looking at others through the lenses of his own culture.

In the same way, Geertz (1983) mentions the case of the work of Bronislaw Malinowski that was released after his death. The book entitled A Diary in the Strict Sense of the Term, which was published in 1967, "rendered established accounts of how anthropologists work as implausible" (Geertz, 1983, p. 56). It effectively demolished the work of anthropologists. In his posthumously published book, Malinowski, who was considered one of the most remarkable figures in the history of anthropology, perhaps has gone too far on the way he presents himself as a moral character. Geertz (1983) points out that "he had rude things to say about the natives he was living with, and rude words to say it in. He spent a great deal of his time wishing he was elsewhere" (p. 56). Moreover, Geertz analyzes the issue raised by Malinowski's book not as a moral but as an epistemological issue, because "the moral idealization of fieldworkers is a mere sentimentality in the first place, when it is not self-congratulation or a guild pretense" (Geertz, 1983, p. 56). In stating this, Geertz suggests that anthropologists need to study humankind from "the native's point of view" or, as he puts it, from "a sort of transcultural identification" (1983, p. 56) in which there is a great difference between knowing and understanding someone's culture (Geertz uses the hermeneutical term understanding, in German, Verstehen), a type of feeling oneself into or getting into/projecting oneself into the atmosphere of... (In German, and as used by Geertz, Einfühlen). In this sense, it seems that it is anthropologically important to investigate and analyze the role of someone in his/her culture relating to one or more cultures, but especially taking into consideration the particular way the native lives, feels, and projects 
himself into the atmosphere and context of the situation he is in. According to Geertz, anthropological analysis could easily be explained by two concepts suggested by the psychoanalyst Heinz Kohut: "experience-near" and “experience-distant” (Geertz, 1983, p. 57).

In short, experience-near is a concept in which someone who is part of a culture can "define what he or his fellows see, feel, think, imagine, and so on, and which he would readily understand when similarly applied by others" (Geertz, 1983, p. 57). Experience-distant, however, is someone who is a specialist of a culture and then interprets and understands a culture through some distance investigation, as a scientist, for instance.

What Geertz suggests is that anthropological analysis needs to be conducted and framed through the balance of both concepts and the attitudes they point to. What he suggests in relation to the native's case, raised by Malinowski, is that "you don't have to be one to know one" (Geertz, 1983, p. 57); but one should attempt to do more than describe (experience-near); the ideal is to interpret and understand (Verstehen) the other from within the other's entire lifeworld. Thus, anthropological analysis can be conducted in this way and it can be distinguished from mere judgments and opinions about the ethical and moral understandings of a people's culture.

\section{The Concept of Person or "What a Self is"}

It is in connection with this "experience-near" concept that Geertz explains the type of work he conducts as an anthropologist. He emphasizes the analysis of the other with the attempt of defining "what a self is" or, as he puts, "the most intimate of the notions" about a people or culture (Geertz, 1983, p. 58). By studying Javanese, Balinese, and Moroccan cultural styles, he seems to go beyond the boundaries of seeing, feeling, and imaging in order to understand the others (experience-near vs. experience-distant). Geertz (1983) attempts to understand the person other than himself "by searching out and analyzing the symbolic forms - words, images, institutions, behaviors” (p. 58), not only to understand how those people were representing their own reality to themselves but also to others.
Moreover, in order to develop an analysis of symbolic forms presented by Geertz, one might take into account another type of understanding, a sociological understanding on ethics and the changes it promotes. According to McCarthy (2013) "ethics are a vital part of social worlds; they are also historically variable, given to change - especially change in people's social imaginary: how they construe persons, their relations with other, the world they share with them, and the moral order to which they belong" (p. 2). Therefore, by confronting our way of living with different cultures, when putting one people's representations into interpretative perspective, one may assess this activity by relating one area to another; that is; we tend to judge other ways of life through what Geertz (1983) calls "the social history of the moral imagination":

(...) the tracing out of the way in which our sense of ourselves and others - ourselves amidst others - is affected not only by our traffic with our own cultural forms but to a significant extent by the characterization of forms not immediately ours by anthropologists, critics, historians, and so on, who make them, reworked and redirected, derivatively ours. Particularly in the modern world, where very little that is distant, past, or esoteric that someone can find something out about goes undescribed and we live immersed in meta-commentary (what Trilling thinks about what Geertz thinks about what the Balinese think, and what Geertz thinks about that), our consciousness is shaped at least as much by how things supposedly look to others, somewhere else in the lifeline of the world, as by how they look here, where we are, now to us. (p. 8)

In this sense, it seems to be important to set aside the conception of what a person is that has been immensely diffused in the West, that is how we judge the moral lives of others. Geertz tackles this issue and suggests that in order to understand what a person is in another culture, it is necessary to do it by "setting that [one's own] conception aside and seeing their experiences within the framework of their own idea of what selfhood is" (Geertz, 1983, p. 59).

As an example, Geertz (1983) describes Javanese culture he studied in the 1950s as having a type of 
reflective intensity even though for those peoples "the future seemed about as remote as the past" (p. 60). Unlike Twain's observations on the others (Robbins, 1993), Geertz (1983) gives us a richer reflection precisely because he does so by considering Javanese culture in a broader perspective:

(...) Yet in the midst of this depressing scene there was an absolutely astonishing intellectual vitality, a philosophical passion really, and a popular one besides, to track the riddles of existence right down to the ground. Destitute peasants would discuss questions of freedom of the will, illiterate tradesmen discoursed on the properties of God, common laborers had theories about the relations between reason and passion, the nature of time, or the reliability of the senses. And, perhaps most importantly, the problem of the self - its nature, function, and mode of operation - was pursued with the sort of reflective intensity one could find among ourselves in only the most recherché settings indeed. (p. 60)

Geertz states that the way the Javanese comprehend "what a self is" can be organized "into two sets of contrasts, at base religious, one between "inside" and "outside" (1983, p. 60). He develops this idea based on the meanings of two terms commonly used by Javanese people that go beyond the theory and forms the conception of the self of the Javanese - "together they formed a distinctive conception of the self which, far from being merely theoretical, was the one in terms of which Javanese in fact perceived one another and, of course, themselves" (Geertz, 1983, p. 60). Geertz (1983) explains that the words batin and lair (both originally from Muslim tradition and locally adapted) "refer on the one hand to the felt realm of human experience and on the other to the observed realm of human behavior" (p. 60). One might associate the Javanese terms with the ones of the Western culture: the concepts of soul and body (in Latin, anima and corpore) which represent the inner and outer world. In Javanese culture, "inside" represents the experiential world, while the "outside" represents the behavioral world.

Geertz notes that these two sets of phenomena are "independent realms of being" (1983, p. 61).
Even though the two sets of phenomena work independently, they have the same goal. What Geertz points out next is that Javanese people believe that both realms of the self (batin and lair) must achieve the equilibrium, i.e. alus, not the kasar. According to Geertz's observations, kasar is a "word meaning 'impolite', 'rough', 'uncivilized', 'coarse', 'insensitive', 'vulgar" while the word alus means "pure', 'refined', 'polished', 'exquisite', 'ethereal', 'subtle', 'civilized', 'smooth"' (1983, p. 61). On the one hand, in order to achieve such equilibrium, Javanese need to work the spiritual, celestial, and heavenly sphere, i.e. the inner realm/inward feelings, through religious discipline. On the other hand, to achieve alus in the external/outer realm it is required to achieve it through etiquette, i.e., "rules of which here are not only extraordinarily elaborate but have something of the force of law" (Geertz, 1983, p. 61). In addition to that, Geertz observes that it is through meditation that "the civilized man thins out his emotional life to a kind of constant hum" and through etiquette that he "shields life from external disruptions and regularizes his outer behavior in such a way that it appears to others as predictable, undisturbing, elegant" (1983, p. 61). In a way, Javanese people might try to compensate one realm into the other to achieve alus. This is part of their existence and, most importantly, part of their cultural understanding of what a self is. They demonstrate their outward actions according to moral and existential accounts, i.e., "to the felt realm of human experience" (Geertz, 1983, p. 60). In fact, they might take into consideration the dialogue with their conscience in order to morally behave in Javanese society.

\section{The question of Self and Moral Analysis on Jane Austen's Novels}

The inner realm (or inward feelings), that is, the essential part to achieve the alus in the Javanese culture, is also what Jane Austen seems to develop in her novels. This observation could be reached through the study of some scholarly work by those who found that moral debates align with some sort of "spirituality" assigned 
in Austen's works. In this way, the cultural implication of this debate might somehow meet the anthropological questions raised by Geertz (1983).

For example, according to Bloom (2009, p. vi), "Austen has no more a political or social agenda than she has a religious one", in a sense that the background that underlies her stories are much more existential and spiritual accounts than social commentaries. Lewis (2009) also points out that Jane Austen construes language to describe Marianne's errors, in Sense and Sensibility, in order to present her ethical and moral positions found in her novels in a religious tone:

(...) The situation has come near to tragedy; moral, as well as, or more than, intellectual deficiency has been involved in Marianne's errors. Hence the very vocabulary of the passage strikes a note unfamiliar in Jane Austen's style. It makes explicit, for once, the religious background of the author's ethical position. Hence such theological or nearly theological words as "penitence", even "the torture of penitence", "amendment", "self-destruction", "my God". And though not all younger readers may at once recognize it, the words "serious reflection" belong to the same region. In times which men now in their fifties can remember, the adjective "serious" ("serious reading", "Does he ever think about serious matters?") had indisputably religious overtones. (Lewis, 2009 , p. 106, emphasis added)

The two observations by Bloom and Lewis identify the inner realm found in Austen's work, mainly in the way she implicitly develops her ironies throughout her stories. The experience, i.e. the inner realm of self, of the characters created by Austen is part of her ironies "which remain invisible because they are so controlled" by her characters' capacities for self-monitoring and selfcontrol (Bloom, 2009, p. vi). Bloom even argues that the irony "hardly accounts for the effect of moral and spiritual power that she so constantly conveys, however implicitly or obliquely" (2009, p. vi). We interpret this to mean that the readers of Austen can realize that the religious or spiritual tone that she implies in her stories cannot be understood through moral contents, conspicuous religiosity, self-conscious virtue, and, most importantly, in accordance with group values and ethics. In order to grasp the complexity of Austen's heroines it is necessary to get rid of the "isms" we are used to as we insert ourselves into a particular culture. For instance, it would be interesting to imagine reading her novels without being a feminist, or a socialist, or any type of belief that we may ourselves pursue. As readers, we need to understand her characters through Austen's wisdom, or as Bloom puts it, "you need to acquire a touch of Austen's own wisdom (...) Austen urges us to clear our mind of 'cant"' (2009, p. vi). In this sense, it is necessary to emphasize the morals of Austen's time as used in her novels as described by Lewis (2009):

(...) the great abstract nouns of the classical
English moralists are unblushingly and
uncompromisingly used: good sense, courage,
contentment, fortitude, "some duty neglected,
some failing indulged," impropriety, indelicacy,
generous candor, blamable distrust, just
humiliation, vanity, folly, ignorance, reason.
These are the concepts by which Jane Austen
grasps the world. (p. 107-8)

Austen seems to have the ability to promote moralism and ethical values in the stories of her time and also to create a world of timeless ethical and moral experiences for her readers today. As one critic stated, “Austen's strangely familiar world constitutes a timeless pocket of human experience, and her observations concerning human nature are just as valid now as they were then" (Carson, 2009, p. xiv). In short, the way Austen construes her characters invites identification with the reader: we might identify ourselves with her stories asking, "Who can resist believing that she too, possesses the 'fine eyes' of Elizabeth? Or the common sense of Elinor? Who is not tempted to strike Darcy's pose of aristocratic disdain? To fancy an irresistible rake like Willoughby?" (Carson, 2009, p. xiv). Thus, it is very likely that the greatest asset of the author is the description of the characters of a society of her time that surpass their historicity and depict not only their experiences, but our own moral behavior. Despite the appearance of the timelessness of her work, perhaps the most difficult thing for today's reader is to recognize 
that some of the moral principles of Austen's time do not remain the same in our modern time:

(...) the best way to understand both ourselves and these fictional early-nineteenth-century beings is to consider how much the world has changed, not just in the outward trappings of coaches, costumes, and architecture, but in the invisible claims of duty, honor, status, family, money, and love. (Carson, 2009, p. xvii, emphasis added)

In addition, it may also be indispensable to recognize that the ethical and moral behaviors of Regency England have been developing and, most importantly, they have been adapted to our times. Carson (2009) raises this issue by illustrating it with some of the passages in Austen's works:

(...) If the young Wentworth proposed to Anne today, for instance, would Lady Russell be able to persuade her to reject him? Would we reject him? Understanding why Anne did reject Wentworth's first proposal requires us to recognize that social prospects had great weight in Austen's world than they do in ours. Would a modern Edward Ferrars maintain a loveless relationship with Lucy Steele? Wouldn't we break off such an engagement? Again, comprehending Edward's faithfulness demands that we acknowledge a code of honor that has all but disappeared. If the stories were told today, these obstacles would not exist and so the novels themselves would not exist: Anne and Wentworth, Elinor and Edward would have married immediately and their stories would have ended before they had even begun. To understand the main conflict both of these novels and to enjoy the full satisfaction of their happy resolutions, we must reinvest this obsolete moral code with its full consequence. (pp. xv-xvi, emphasis added)

Although "the subject matter of Austen's novels is historically embedded", one may realize that some essayists and literary critics situate them with respect to timelessness and moral significance, as can also be seen in Lionel Trilling (2009), "Why We Read Jane Austen", and in C. S. Lewis (2009), "A Note on Jane Austen".
Carson (2009) reports that morals are part of the essay of Lewis in which he "cites Austen's 'hard core of morality"' (p. xviii). On the other hand, Trilling's essay is about the seeming timelessness of Austen's works because they "reflect on the perennial relevance of her 'sacred wisdom"' (p. xix). The experiential atmosphere developed in her novels through the context of situation and characters may reveal more than a religious tone, as noted earlier; it may reflect Austen's morality in a way that is also "an account of mature human interaction", as noted by Carson (2009, p. xix).

\section{Moral Remarks on Some Significant Aspects of Austen's Novels}

As was mentioned earlier, the religious tone found in Austen's novels might represent the moral principles concerning the distinction between right and wrong or good and bad behavior that guides her stories. This religious tone might set the moral and ethical world created by the author and may also define Austen not only as a literary author but as a figure of moral significance for her many readers from the twentieth to the twenty-first century. According to Trilling (2009), figures like Austen are

(...) creative spirits whose work requires an especially conscientious study because in it are to be discerned significances, even mysteries, even powers, which carry it beyond what in a loose and general sense we call literature, beyond even what we think of as very good literature, and bring it to as close an approximation of a sacred wisdom as can be achieved in our culture. (p. 59)

Austen's works - however historically situated become part of our own "moral imagination". In this sense, Austen also can be considered a figure because, as noted by Carson (2009, p. xv), "Austen's entire mode of perception, from the arrangement of words to the arching sweep of the stories, is so persuasive that we often find ourselves converted to the unique sect of what Lionel Trilling terms her 'secular wisdom'”. Taking into account the moral value of the body of Austen's 
work, one may say that Trilling's observation on why so many of his 1970s college students wanted to apply themselves in the course on Jane Austen is relevant. The students "had formed the impression that Jane Austen's novels presented a mode of life which brought into question the life they themselves lived and because it offered itself to their fantasy as an alternative to their own mode of life" (Trilling, 2009, p. 61). Perhaps, what can be observed is that by studying Austen's works, Trilling's students might be in contact with a more inviting world than their own. They wanted

(...) in some way [to] transcend our sad contemporary existence, that, from the world of our present weariness and desiccation, they might reach back to a world which, as it appears to the mind's eye, is so much more abundantly provided with trees than with people, a world in whose green shade of life for a moment might be a green thought. (Trilling, 2009, p. 61)

In order to understand why Trilling's students were so eager to attend his lecture on Austen delivered at Columbia University in 1974 , it is necessary to understand his students' "impetus from feelings about social existence" (Trilling, 2009, p. 61). Trilling (2009) points out that "in general it is a thing taken for granted by readers that the novels represent a world which is distinctly, even though implicitly, gratifying to the eye and to the whole sensory and cognitive system" (p. 62). Austen invites her readers to be part of a pleasant place even when she does not entirely describe them in the body of her novels. The description of her novels' scenes can give the reader a sense of happy enjoyment. Therefore, the effect of social convention portrayed by Austen can also be understood by what Trilling (2009) calls "scale, the relation in size between human beings and the components of their environment" (p. 62). The sort of scale presented by Austen is one in which "the judgment goes that the most salubrious situation is one in which moderate though generous size conveys the idea of happy accommodation" (Trilling, 2009, p. 62). The way Austen "weighs" the moral descriptions of her characters along with the contextual scenes in old England represents the spiritual aspirations of Trilling's students in modern times: the students "felt the need to see persons represented as novels once typically represented them, without formulating their need, they were in effect making a stand against the novel in its contemporary mode" (p. 63). The students seem to morally judge what is harmful. In Trilling's words (2009), they

(...) saw the contemporary novel as being of a piece with those elements of the modern dispensation which they judged to be maleficent, such as industrialism, urbanization, the multiversity. This maleficence would have to do with the reduction of their selfhood, and presumably it could be neutralized by acquaintance with the characters of Jane Austen's novels, an association that was indeed licensed by the aesthetic of the works. That is, these fictive persons would be experienced as if they had actual existence, as if their "values" were available to assessment, as if their destinies bore upon one's own, and as if their styles of behavior and feeling must inevitably have a consequence in one's own behavior and feeling. (p. 63)

The way the students were feeling while reading Austen's novels can be, in fact, a fulfillment of the aim of traditional humanistic education, as Trilling (2009) himself observed

(...) in reading about the conduct of other people as presented by a writer highly endowed with moral imagination and in consenting to see this conduct as relevant to their own, they had undertaken an activity which humanism holds to be precious, in that it redeems the individual from moral torpor; its communal effect is often said to be decisive in human existence. (p. 63)

In this sense, when Trilling's students read Austen, they are not only interested in "the good effect of reading about the conduct of other people of one's time". Because humanism goes beyond that, "it does put a special value upon ranging backward in time to find in a past culture the paradigms by which our own moral lives are put to test" (Trilling, 2009, p. 63). Hence, 
the interaction between our own time and others' times in relation to moral values is not problematic, because humanism is

\begin{abstract}
(...) confident that the paradigms will be properly derived and that the judgments made on the basis they offer will be valid. Humanism takes for granted that any culture of the past out of which has come a work of art that commands our interest must be the product, and also, of course, the shaping condition, of minds which are essentially the same as our own. (Trilling, 2009, p. 64)
\end{abstract}

However, the question Trilling (2009) raises in his essay concerns "a great range of existential differences" (p. 64) that Austen's novels evoke, in particular the problem of us. He illustrates his point with a word - work ethic - that was traditionally used in discourse about society that his students may have difficulty in understanding, since it has acquired different meanings in our current society. He states that the word meanings are so different if compared to ours nowadays that, even reaching an agreement about the conventions, "the system of status, and deference on which the novels are based", the students "were never quite easy with it and didn't finally believe in its actuality" (Trilling, 2009, p. 64).

Trilling emphasizes three remarks noted by him in relation to his students' observations. In 1974, when his course was being taught, from his students' perspectives it seems the "work ethic" was related to representative roles performed by Austen's characters in old England rather than their own society. In fact, England portrayed by Austen was much more embedded in an aristocratic representation of people, in which there was a representative function performed by people in society (people tended to be in military service, for example) rather than what Americans conceived as being the "work ethic", i.e. representative roles performed by doing a task at the workplace. Despite these very real differences, Trilling notes that his students did not think that Austen's society was different from their own, "in which most persons naturally thought that life consisted not of doing but only of being" (Trilling, 2009, p. 65). As a second point, Trilling raises the question of the extent to which someone might be "morally conscious". He illustrates his idea by quoting two similar lines used by two distinct characters in Austen's novels (Anne Elliot in Persuasion and Elinor Dashwood in Sense and Sensibility). At this point, it seems that the representative function of women of that time can be morally understood by the word "duty". Both Anne and Elinor represent the work done by women in old England as the sense of moral obligation rather than for pleasure. Even though, this cultural understanding does not seem to negatively represent them. As Anne Eliot said to Captain Wentworth in one of the passages of Persuasion "strong sense of duty is no bad part of a woman's portion" (as cited by Trilling, 2009, p. 65); this can have a more complicated interpretation when brought to our contemporary cultural understanding. The third remark he makes is in relation to "manners as small morals", a concept assigned to Hobbes: the social behaviors or habits performed by Austen's characters can be perceived as ways the author presents to her readers the sexual mores of her own society (Trilling, 2009). In fact, Trilling concludes that most literary and humanistic commentary on Austen's novels shows not the similarity between them and us but the dissimilarity of our moral lives if compared to those inhabitants of Austen's social world.

Thus, comparing Trilling's arguments about comprehending another's culture and comparing them to Geertz's ethnographic argument, one may see that Trilling explains how difficult is the process of intercultural understanding from one era and society to another, and even how they differ in the way of understanding what a self is (Geertz, 1983). So Geertz and Trilling offer similar but also very different arguments. Geertz's aim is to understand the native's point of view on what a person is. Trilling's "humanism" attempts to understand (using empathy) a story about people foreign to himself: an Icelandic story called "Audun and the Bear". In fact, Trilling follows the suggestion of Geertz on how to understand others. He reports his understanding as follows: 
(...) I had no difficulty in "understanding" this story. I did exactly what Mr. Geertz says he does not do when he wants to arrive at the understanding of what a self is in an alien culture: I made use of empathy, I imagined myself someone else, a not very well-off man from the Westfirths, and this seemed to suit my purpose admirably, leading me to know all that I felt I needed to know about bears ant their excellence, and kings, and gift giving. (Trilling, 2009, p. 68)

However similar these literary and anthropological projects are, and they are similar in important respects, here are important differences in reading Jane Austen and conversing with and writing the culture of Java. In order to "know" the culture represented in Austen's novels or to understand the Icelandic story, we might "understand it because it is part of 'Western' culture and as such pretty directly continuous with our own culture of the present time" (Trilling, 2009, p. 68). However, one may consider and understand through an ethnographic approach that what Javanese natives think and speak about persons requires a different analysis and requires much more than empathy. It requires a careful study in a native's general form of life, asking: "What exactly are the vehicles in which that form is embodied?" (as cited by Trilling, 2009, p. 67). These then are different questions and require different methods.

Thus, the question that remains with regard to the way we assess our conduct as well as how we evaluate others might be explained by a passage of Persuasion offered by C.S. Lewis. In this passage, Anne uses moral standards to evaluate Mr. Elliot:

(...) she ventured to recommend a larger allowance of prose in his daily study, and... mentioned such works of our best moralists, such collections of the finest letters, such memoirs of characters of worth and suffering, as occurred to her at the moment as calculated to rouse and fortify the mind by the highest precepts and the strongest examples of moral and religious endurances (Persuasion, Chapter 11, as cited in Lewis, 2009, p. 110)

In fact, the way we see the world we live in is undoubtedly a factor we use when we judge the morals and ethical behaviors of others. Austen's plots suggest that context plays a crucial role in construing the morality and religious tone suggested by her novels. According to Lewis (2009), “'principles' and 'seriousness' are essential to Jane Austen's art. Where there is no norm, nothing can be ridiculous, except for a brief moment of unbalanced provincialism in which we may laugh at the merely unfamiliar" (pp. 113-4). Hence, we can judge her characters' moral behaviors in a humorous way or we can then realize how ridiculous and impossible such ethical actions portrayed in Austen's novel might be in our own world. Most importantly is the way that Lewis (2009) depicts the moral world construed by Austen: he suggests that in construing the moral world of her novels, Austen depicts it from within a suffering and painful background in order to (implicitly) offer her own system of ethical and moral values.

\section{Final remarks}

By presenting these reflections on the intercultural understandings of "different" worlds, one can see that the main core of these investigations is how differently we can morally interpret one's own and another's culture. For example, how we interpret and understand the question of us and them, can be understood in a wide range of moral judgments: personal (as noted in Twain's observations), from the native's point of view (as explained by Geertz), from Austen's time to ours (as observed by Trilling on his students' reactions), and also from a spiritual account or religious perspective (as suggested by Lewis).

As one can see, the problem of "culture" in the process of intercultural understanding can be analyzed through different types of lenses or frames. The ones presented in this paper may converge with ideas as well as diverge in the approaches presented. For instance, Geertz explains that it is most important to know and understand a culture from the native's point of view. In this sense, we investigate another's culture by examining its main core. In addition, Trilling demonstrates, through his observations on his students' reactions about Austen's works, that one might feel lost in the middle of the moral world portrayed by Austen, but, at the same time, as modern readers of Austen, one can discover 
oneself intertwined within this imagined world - words, meanings, habits, and moral codes. It might even be claimed that Trilling's students may compare their own ethics with those of Austen's characters in order to achieve and develop a broader and richer intercultural understanding, as humanism has argued.

Finally, in order to answer the question, "How can we describe and analyze a cultural practice that is so different from the perspective of our own culture?" one can find an answer from a citation of Geertz at the end of his essay, "From the Native's Point of View". Geertz states that it is not from direct experience that we can understand others' cultural perspectives, but "it comes from the ability to construe their modes of expression, what I would call their symbol systems, which such an acceptance allows one to work toward developing [...] it is like achieving communion" (Geertz, 1983, p. 70). On this point, Geertz and Taylor (1992) find common ground: despite our moral and ethical differences, we can engage ourselves in a relationship of recognition and acceptance of others' cultures, as if they were our own.

\section{References}

Austen, J. (1983). Sense and Sensibility. New York: Bantam Books.

Pride and Prejudice. New York: W.W. Norton \& Company.

(1995). Persuasion. New York: W.W. Norton \& Company.

Bloom, H. (2009). Foreword. In L. Carson, S. (Ed.), A truth universally acknowledged: 33 great writers on why we read Jane Austen. New York, NY: Random House, pp. v-x.

(2007). Jane Austen's Pride and Prejudice: Modern Critical Interpretations. New York: Chelsea House Publishers.

Carson, S. (2009). Introduction. In Carson, S. (Ed.), A truth universally acknowledged: 33 great writers on why we read Jane Austen. New York: Random House, pp. $\mathrm{xi}-\mathrm{xx}$.

Geertz, C. (1983). "From the Native's Point of View": On the Nature of Anthropological Understanding. In Local Knowledge: Further Essays in Interpretive Anthropology. Clifford Geertz. pp. 55-70. New York: Basic Books.

Lewis, C. S. (2009). A Note on Jane Austen. In Carson, S. (Ed.), A Truth Universally Acknowledged: 33 Great
Writers on Why We Read Jane Austen. New York: Random House, pp. 104-115.

McCarthy, E. D. (2013). What's Cultural About Ethics? Using Social Theory to Frame Ethics. New York: Fordham University - Ethics and Society Workshop. Unpublished.

Robbins, R. H. (1993). Cultural anthropology: A problembased approach. Itasca, IL: F.E. Peacock Publishers, Inc.

Taylor, C. (1989). The Sources of the Self: The Making of the Modern Identity. Cambridge: Harvard.

. (1992). The Politics of Recognition. In Taylor, C. (Ed.), Multiculturalism \& 'The Politics of Recognition'. New Jersey: Princeton University Press, pp. 25-73.

Trilling, L. (2009). From "Why We Read Jane Austen". In Carson, S. (Ed.), A Truth Universally Acknowledged: 33 Great Writers on Why We Read Jane Austen. New York: Random House, pp. 57-69.

Recebido em: 25/8/2015 Aceito em: 10/11/2015 